\title{
Constructing borderland identities in Romania and Bulgaria: the case of interwar Dobruja (1912-1939)
}

\author{
Ana-Teodora Kurkina
}

Review article

UDK 321.013(497Dobruja)"1912/1939"

\begin{abstract}
This paper addresses the shifting identities of a disputed borderland territory, using the interwar Dobruja province as an example, and following the transformation of its political and ethnic boundaries through the eyes of various public participants in the dispute. Their views are explored as vital sources which reflect Bulgarian and Romanian policies in the region and their interactions with the Great Powers. The paper indicates that identity debates had very little influence on the actual population of the region, appealing mainly to various external powers and the political and intellectual "elites" of both countries. A state is viewed as a system of social networks, therefore a contested border becomes a space where those interconnections assume the roles of nationalizing markers. Therefore, the paper proposes to regard a borderland dispute not as a typical pattern of othering, but as an attempt to establish interconnections and make it even more "national" than the regions non-contested.
\end{abstract}

Keywords: Balkan studies, borderland disputes, state-building in the Balkans, Dobruja, Romanian/Bulgarian political thought, social networks. 


\section{Identifying a border}

The Dobrujan question, which first emerged after the signing of the Treaty of Berlin in 1878, became a vital issue in Romanian-Bulgarian relations after the Second Balkan War and Romanian expansion into the southern part of the region, Cadrilater. The territorial exchange that followed transformed the province into an arena for Bulgarian and Romanian nationalist propaganda, characterized by competing state- and nation-building projects, identity debates and modernization programs (Kuzmanova 1989: 18-19). Presenting a case of shifting identities based on territorial disputes, the current text goes beyond descriptions of post-Ottoman integration strategies in the Balkans and focuses on the publications of several participants on both sides of the debate. Those accounts, in turn, reflect the persistent attempts by these participants to establish viable social and ideological interconnections between the contested territory and their respective states.

While dealing with multiple regional entanglements (Marinov 2013: 3-13), the paper does not simply address the concept of "othering" applied to the advancement of various Bulgarian and Romanian state-building strategies (Mishkova 2008; Aretov 2012: 89-97), but rather proposes to view a borderland as a fluid space where social networks form. Furthermore, these networks, whether recent or long-standing, are based on certain legacies that render them "legitimate". A state, as well as a nation, based on denial and/or acceptance of multiple previous, always reinterpreted and reformulated legacies (Todorova 2004: 5), remains a subtle mechanism for primarily advancing the agendas of those who are actively involved in nation-building disputes. Taking the case of interwar Dobruja as an example, this paper strives to represent the construction of borderland identities as a project initially conceived by several prominent public actors and employed by the state in order to accommodate inevitable differences, yet excluding the opinions of the local population to a considerable extent. It had to be either incorporated or expelled from political life (Mylonas 2012: 17-21). Therefore, the borderland became the ultimate battlefield, where identities were formed when a viable connection between a legacy and a social network was established. This pattern, based on the example of Dobruja, a geographical boundary dividing and connecting two neighbouring nation-states, can be applied to other, similar cases of contested regions with mixed populations. 
If a state can be viewed as a set of functioning interconnections, then the issue of "othering" and mutual Balkanization turns into a quest for establishing cultural, historical and political links between a region and the core of an idealized nation-state. In this case, the actual identities of the inhabitants of the land had little significance to the prominent public participants involved in the debates. The population could be resettled, reshaped or suppressed with varying degrees of success (Dragostinova 2009: 185-212). What truly mattered for the state-builders was "region-branding", the creation of a "suitable identity". Furthermore, they clung to the idea of a direct link between their respective state and a borderland zone predictably contested and challenged by their opponents.

From the $15^{\text {th }}$ century onward, Dobrogea functioned as a border zone of the Ottoman Empire and one of the most forward Muslim military bastions in South-eastern Europe. Between 1768 and 1878, the province served as a transit corridor and military battlefield in a long series of Russo-Ottoman wars (lordachi 2002: 1-2). Ottoman control over Dobruja lasted until 1878, when the Great Powers at the Congress of Berlin ceded the region, together with the Danube Delta, to Romania, while its southern portion remained with the newlyestablished Bulgaria. In return for this new possession, Romania had to cede Bessarabia to Russia (Michelson 1989); this requirement, however, aroused great controversy in Romanian political elite circles. Frederick Kellogg noted that Romanian Foreign Minister Mihail Kogălniceanu viewed Dobruja primarily as a boundary that could keep Russia away from the Danube, while Ion Brătianu, Romania's prime minister and a notable politician, saw it as a vital region for free navigation on the Danube (Kellog 1995: 199-201).

Dobruja, with its ethnic diversity, could not be easily incorporated into either Bulgaria or Romania: at around 1880, a plurality of the north Dobrujan population consisted of Turks and Tatars (Dănescu 1903: 15-20; Vakarelski 1964: 9). Even in 1930, after a number of significant changes had affected the region in the preceding decades, $22.4 \%$ of the entire Dobrujan population (which already was already incorporated into Greater Romania) considered Turkish their mother tongue (Mihăilescu et al. 1938: 620). 
"Identity" in the case of disputed territories had little to do with individual self-identification and was rather a project of various intellectual circles trying to appropriate the land. ${ }^{1}$ In the case of Dobruja, those elites relied heavily on the re-interpreted Western experiences of modernization and state-building (Daskalov, Mishkova 2013: 1-99). Therefore, the disputed land and its significance reflected the state-building projects of the subsequent country. In multi-cultural Dobruja, the identity of its population before the debate was hardly prominent and politically voiced. Hence, the idea underlying Romanian state-building propaganda went beyond the simple creation of a new identity for the local Lipovans, Bulgarians, Turks and Tatars, also assuming the "export" of suitable "Romanians" to the province, while marking the space as culturally Romanian (Kuzmanova 1989: 17-18). Therefore, one may refer not to a case of an "identity creation", but rather to a viable pattern of establishing and cultivating links that, in their turn, would spur identities that could fit into a grander state-building plan.

\section{"Nationalizing" a region}

On November 5, 1913, Simeon Radev, a Bulgarian historian, journalist, diplomat and politician, wrote to Bulgarian Foreign Minister Nikola Genadiev regarding the stance of Austrian-Hungarian diplomacy on the status of Dobruja in Bulgarian-Romanian relations: "Prince Furstenberg has conveyed to me his impressions after having spoken with the king in the following form: 'All Romanians, beginning with the king, perceive the physical superiority of the Bulgarian over the Romanian race'. ${ }^{2}$ They are convinced that even within the limits of today's borders, Bulgaria will become the greatest military power among the Balkan states" (Radev 1913/1992: 237). This account by Radev still contains traces of doubt over the seriousness of the Romanian plans concerning Cadrilater, the southern part of the region. Radev, deeply involved in the diplomatic affairs which later resulted in the signing of the Treaty of Bucharest

\footnotetext{
${ }^{1}$ In most cases, the population remained indifferent to the fierce debates of the so-called public figures and politicians either in Romania or Bulgaria, reacting only in cases of the latter's direct involvement with the well-being of local residents. Regarding the concept of "indifference", see Rudolf Stichweh (Stichweh 1997: 1-16).

2 It should be noted that Radev's use of the word "race" refers more to the superior cultural and historical heritage of the Bulgarians, rather than bloodlines specifically, which he did not present as an argument later.
} 
and himself becoming minister plenipotentiary in the Romanian capital, fully realized that the treaty would lead to devastating consequences and the loss of lands unless Bulgaria adapted to the situation. Radev's country had to continue considering itself the greatest power on the Balkans, employing a sort of a selfdirected propaganda that necessarily also influenced its opponents and potential allies. $^{3}$

Similarly to Bulgaria, Romania had to adopt strategies that would allow portrayal of the full incorporation of Dobruja into the country as a natural outcome of a state-building process that had already taken root in "prepared" soil. For the Romanian side, the mere idea of annexation of Cadrilater initially appeared almost as contradictory as the previous dispute regarding Northern Dobruja (Hitchins 1994: 153-157; lordachi 2002: 9-10; Ungureanu 2005: 19-25; Kuzmanova 1989: 18-19). In the 1940s, Mihail Manoilescu, a Romanian journalist, politician and later foreign minister, wrote about the annexation of Cadrilater: "Research into the documents from the Bucharest Peace Treaty of 1913, undertaken by officials of the Ministry at my behest, did not yield even a trace of justification for the annexation of Cadrilater other than the foolish point regarding the strategic border, compounded by the shameful argument concerning compensation for Bulgarian territorial growth" (Manoilescu 1991: 179).

The "justification" was a vital aspect of establishing a link between Dobruja and the rest of the Romanian lands. Therefore, it was hardly the opinion of its population or its continually fluid allegiances that truly mattered. The "regional identity" existed in the heads of the prominent public actors, who grasped for Dobruja as a strategically important piece of land with the vestiges of certain legacies "primed for interpretation". Therefore, Romanian archaeologists working in the province created its identity and established links with the fluid body of the nation just as successfully as did prominent political actors (Hamilakis 2007). They provided "physical proof" of the presence of a needed legacy, as in the case of Vasile Pârvan conducting his excavations in Dobruja (Culea 1928: 9). The findings were, consequently, supported by the always effective civilizational claim (Iordachi 2000: 239-264). Although the Romanian "civilizing mission" of struggling against underdevelopment in a

${ }^{3}$ For further details on Radev's views and considerations about the period preceding and following the treaty of Berlin, see his major work Строителитена съвременна България/The Builders of the Modern Bulgaria (Radev 1973). 
formerly backward Ottoman region had its own particularities, it was not too different from the Bulgarian idea of being the most developed and accomplished nation in the region. In both cases, the territory had to be appropriately branded in order to render it as part of the state (it could be both the Roman legacy and the heritage of the Second Bulgarian Empire). In both variants, this "nationalization" was accomplished not by simple othering, but through a carefully moulded link. Subsequently, those cultural and historical links to the modern state were thwarted by their respective opponents and both propagandistic strategies clashed (Schmidt-Rösler 1994: 101-103).

Bulgarian propaganda in Cadrilater was aimed at mobilizing the Bulgarianoriented population to fight against Romanian rule through various newspapers, leaflets and volunteers present in the region. Émigré organizations in northern Bulgaria and Sofia stood behind this propaganda; however, according to Romanian propaganda, it came "directly from the Bulgarian government" (Schmidt-Rösler 1994: 101-103). Nevertheless, the Bulgarian government itself did not seem to have any significant control over the Dobrujan organizations that in many cases acted independently and without consent from the Central Powers. Yet they managed to attract a number of influential Bulgarian scholars as well as foreign attention to the Dobrujan dispute, while trying to strike a balance between Germany, France, the newly-formed Turkey and several other world and European Powers.

The peace conference in Paris in 1919 (Nyagulov et al. 2007: 275) did not result in a desirable outcome from the Bulgarian point of view. Dobruja remained under Romania's control. Nevertheless, Romania no longer could successfully appeal to the idea of a "Bulgarian peril" after occupying Bessarabia and Northern Bucovina (Nyagulov et al. 2007: 275-276) and fulfilling the plan of "Greater Romania". From 1919 until the signing of the Treaty of Craiova, Dobruja became the stage for Bulgaria's poorly organized attempts to mobilize the local population and prevent the Romanian side from assimilating and colonizing the region.

For Romania, Dobruja, especially its newly acquired southern part, became a territory open for active propaganda that had to shape Romanian culture in the province. For a task of this magnitude, propaganda had to be created by the state and embrace all the possible facets of life in Dobruja (Nyagulov et al. 2007: 290-301). It had to attract settlers, Aromanians, or migrants from other parts of the country by offering them a place to live and land to cultivate, sustaining the idea of a "flourishing Romanian culture" in the region 
and justifying territorial claims to the land. This "blooming Romanian culture", hardly existent in Northern Dobruja prior to 1878 and virtually non-existent in Cadrilater before 1913 (Livizeanu 1995), required state investments.

In this case the border became a meeting point of the two "civilizing missions": the Romanian idea of saving the region from barbarism and underdevelopment, and the Bulgarian quest for "Greater Bulgaria". Therefore, the borderland had to be more Bulgarian or Romanian than the rest of these two respective states. The Bulgarian and Romanian civilizing missions were aimed at creating a space where their nation- and state-building ideas would be officially institutionalized. In this case, Romania certainly had leverage, since it controlled Dobruja most of the time during the period under analysis.

\section{Exchanging words}

The texts of several active participants of the territorial debate from both sides represent interesting reflections on the arguments the Romanian and Bulgarian sides commonly used to brand the region. Although they came from different backgrounds, the authors usually presented similar approaches to the issue. They appealed to certain credible legacies and connections in order to prove the markedly Romanian/Bulgarian character of the province and spur new viable cultural links. These protagonists not only included eminent historians such as lorga or Mutafchiev, diplomats, journalists and philosophers, but also, for instance, a former prisoner of war (Vlădescu 1926). Although the texts belong to different genres, including memoirs, novels, leaflets, educational pamphlets and seminar proceedings, all of them refer to Dobruja as a part of the essential and vitally important Romanian/Bulgarian state.

Anastas Ishirkov, ${ }^{4}$ already in the introduction to his work "The Bulgarians in Dobruja", described Dobruja as the natural extension and integral part of the Bulgarian state (Ischirkoff 1919: 8-10). Unlike Romanians, Bulgarians, according to Ishirkov, did not need to "colonize" Dobruja; they only had to mobilize the existing Bulgarian elements in order to regain the territory that had been "paid for by blood". Ishirkov wrote: "The peace of Bucharest in 1918 provoked great disillusionment among the Dobrujan population, especially among the Bulgarians from Northern Dobruja, who thought that they would forever remain under the

\footnotetext{
${ }^{4}$ Also transliterated as Ichirkov and Ischircov, depending on the source and the language of publication.
} 
Romanian yoke. They could not understand how, after all of the sacrifices made by the Bulgarian people, they could again become a bargaining chip for foreign economic and political interests" (Ischirkoff 1919: 126-127). Describing the National congresses of Dobruja, Ishirkov highlighted the existence of a "Bulgarian-feeling" and "Bulgarian-thinking" audience, the "affirmed nation" that was already present in that land. ${ }^{5}$ That nation was, undoubtedly, linked to his nation-state. However, Ishirkov omitted mentioning the Romanian, Tatar, Turkish or any other element of the region's rather non-homogeneous population.

Milan Markov, another Bulgarian voice in the debate, presented very similar arguments, stating that Bulgarian resistance inside Dobruja, various Romanian colonizing attempts and, finally, integration of the entire region into Romania "constitutes in itself the most striking demonstration, originating within Romania itself, of the indisputable Bulgarian character of Dobroudja" (Markov 1917: 32). Attacking the Romanian policy of assimilating the region and "changing its (predominantly Bulgarian, in his view) character, Markov pointed out: "And since the real complexion of the country was of just such a nature, since Dobroudja was totally alien to Romania, it was quite natural that assimilation should also be violent in nature" (Markov 1917: 15). In this case, the polemics acquired new features as they were driven toward the edges of the two cultural programs - the Romanian and the Bulgarian - both aimed at presenting their ideas before foreign and, to a much lesser extent, local (Romanian and Bulgarian) audiences.

Another propagandistic text, the "Memoir from the Central National Council of Dobroudja to the representatives of the states called together to restore the peace among the nations", referred to the Bulgarian ideas of constructing Greater Bulgaria with a homogeneous population and opposing "unbearable Romanian oppression" (Central National Council of Dobroudja 1919: 42). The attacks directed at Romanian domination in Dobruja generally referred to the atrocities committed by the local authorities. In some cases, they cited supporting evidence, while in others they absolutely neglected these aspects: "In normal times, the inhabitants of Dobroudja had even under the Turks all the liberties and almost all the guarantees, which they now have under the

5 A year before 1919, Ischirkoff published another book on the problem of the Dobruja region featuring similar themes, but with more intense economic and political overtones (Ishirkov 1918). 
Romanians", however, they also had "equal rights, which the Romanians could not secure to them" (Central National Council of Dobroudja 1919: 25).

The authors of later texts authors viewed the problem similarly; however, knowing the outcomes of the Treaty of Bucharest better, they accorded more attention to the social and economic aspects of the dispute, trying to represent the links between the respective states and the region as profitable and "natural". Ivan Penakov, for instance, viewed Dobruja not simply as an essential hub of Bulgarian culture, but also as a province that would allow the Bulgarian nation to prosper (Penacoff 1928). Hence, he introduced not only the argument of "natural development and feasible connections", but also addressed the "competing state-building projects" (Penacoff 1928: 46-48). Since "national identity" is always multi-dimensional and impossible to reduce to a single element (Smith 1995: 182), it constitutes a mosaic of multiple re-interpreted legacies. Those legacies become the core of the process of identity construction, which, in fact, is a series of justifications of heritages, manifested in multiple interconnections, as seen in Penakov's text.

Like its Bulgarian counterpart, the Romanian one had to generate elaborate propagandistic strategies in order to construct a splendid image of Romanian Dobruja. The Dobrogea (Stoică 1919), edited by Professor Vasile Stoică, openly referred to "Romania's civilizing work in the region" (Stoică 1919: 13-18). Bulgarian activists apparently viewed these "civilizing actions" as the already mentioned "Romanian oppression". Similar to lorga's "What do we represent in Dobruja?" (Iorga 1910) published before the Treaty of Bucharest was signed, Stoica's work contains familiar intonations when appealing to Romania's Roman heritage in Dobruja, which had to be stressed, since without this piece of land stretching from the Black Sea to the Danube, Romania as a state and Romanians as a nation would have been incomplete.

The idea of "colonization" for making a nation "complete" was very thoroughly elaborated by another Romanian author, Romulus Seişanu, in a book that considered all aspects of the region's life, from its natural resources and ethnical structure in different periods to the province's political history. The colonization of the land, mainly by migrants from Macedonia, was viewed as compensation for the human losses in the war of 1877-1878 (Seişanu 1928: 181187). In the section entitled "The exceptional regime and constitution of Dobruja" (Seişanu 1928: 202), the author underlined the importance of the Romanian nation-state as an "indivisible" network regulated according to an "exceptional 
constitution". ${ }^{6}$ Furthermore, the Romanian side was compensating the absence of the already existing flourishing Romanian culture in Cadrilater before 1913 by claiming to have an "exceptionally" successful nation-state that assured the prosperity of the region within Romania's borders.

\section{Centralizing a country}

It should be noted that even in the Romanian case, one should not focus on one particular centralization project that included Dobruja as one of several provinces that had to be fully integrated and assimilated. Even before union with the Old Kingdom (Wallachia and Moldova), the Romanian National Party in Transylvania and Banat, led by Iuliu Maniu and Alexandru Vaida-Voevod, supported the idea of creating a federal state (Scurtu 1983: 12-13). While it became one of the main parties in the country with significant power and favoured the establishment of autonomous provinces, the National Liberal Party nevertheless imposed its doctrine of high centralization of the country.

The inevitable clash of the two parties resulted in Romania allying with the Entente in 1916 and Ion Brătianu's domination of Romanian politics, which further explained the active attempts at centralization. In 1919, the Peasant Party, which opposed Brătianu's Liberal Party, managed to achieve significant influence for a brief period, only failing in 1922 (Scurtu 1983: 12-13). Consequently, the Dobrujan debate coincided with the dispute concerning the administrative organization of Romania. Arguing with Brătianu's views, Constantin Stere expressed his ideas about the possibility of a federal state, citing the principles of national sovereignty and local autonomy that several of the regions had under foreign rule (Avornic et al. 2008: 2-6; 12). According to Stere, attempts at forced unification of already emancipated regions could not achieve the desirable result of "unity" (Stere 1922: 44-45). The nature of interconnections remained similar, according to Stere, yet the modes for introducing them ignited fierce debates.

The same opinion, albeit expressed more as a "wish for more voluntary options" than for actual political autonomy, was expressed by luliu Maniu, who observed in 1919: "When I declared the unification, I declared it unconditionally, without reserving special provincial rights, because I have and I still faithfully

\footnotetext{
6 Apparently, by "exceptional constitution", Seişanu meant "progressive and innovative Romanian law" (Seişanu 1928: 202).
} 
believe that unified Romania should be one within its legislative parts, one within its governance, one within its spirit, its thought in all the public institutions of the state" (Maniu 1919: 219). Therefore, the main tendency of Romanian statebuilding projects was still that of creating a unified country, and propaganda related to the integration of the provinces was in most cases regulated and supported by the state (Nyagulov et al. 2007: 341-407), which, however, admitted the existence of other views on policies implemented in the regions.

\section{Conclusion: interconnections reshaped}

The political actors on both sides regarded their borderlands as parts of the nation's body that they had to carefully reattach, while creating a system of viable interconnections based on credible legacies. The region's "differences" had to be perfectly accommodated, first and foremost because of its strategic position, i.e., its proximity to the "neighbour". The opinions of local inhabitants mattered little to either highly-educated and prominent scholars like Mutafchiev or lorga, or to various diplomats, journalists and publicists like Milan Markov or Romulus Seişanu. The Dobrujan dispute represents an intriguing example of how astute historians, journalists, writers, diplomats and other active participants in the debate transformed a borderland province of, initially, limited importance (compared to other territories with Romanian and Bulgarian populations) (Roudometof 2002: 5-29; Hitchins 1985) into one of the most crucial focal points that played a major role in the nation-building strategies of both Romanians and Bulgarians.

A nation was "largely an abstract entity that was invoked and symbolized through flags, schools, holiday celebrations" (Karakasidou 1997: 163), while "the state had a very concrete existence to area residents, embodied in the form of civil administrators, tax collectors, and policemen posted to the village" (Karakasidou 1997: 163). Successful incorporation of a territory depended on a variety of economic factors as well as the ability of political activists to properly represent them.

This aspect of "underdevelopment" forced Romania and Bulgaria to attempt to overcome their "backwardness" while investing significant effort into various modernization schemes. Linked to the dissemination of education and

7 The terms of "underdevelopment" and "backwardness" are highly stigmatized and notoriously overused when referring to the Balkan cases and their analysis from the point of view of the dominant European political model.(Roudometof 2000: 144-163) 
culture, which is clearly illustrated by the Bulgarian, Greek or Romanian revivals (Mishkova 1994: 63-93), modernization itself was accompanied by nationalism (Daskalov 1998: 208), which was a driving issue for each of these states. Engaged in establishing patterns of social networking, the political actors from both sides failed to offer viable modernizing plans for the region.

While every borderland dispute is an example of mutual othering and attempts at re-interpreting certain legacies that have to match the dominant nation and state-building narrative, it also encompasses another important tendency. Political actors engaged in constructing borderland identities do not simply refer to identities as such, but in fact, forge important links that connect the borderland to the other parts of the nation-state. So, while othering and reinterpreting legacies remain an important part of the process, the true aim it follows is the creation of an array of interconnections that prove the viability of their claims.

\section{Bibliography}

ARETOV 2012

Aretov, Nikolay, "Balkan variations of Orientalism and Occidentalism," Култура/Culture, Thematic issue: "Europe without borders," 3, Skopje 2012, 89-97.

AVORNIC ET AL. 2008

Gheorghe Avorniași. Raisa Grecu, "Anteproiect de Construcţie - un ipotetic apogeu al realizării practice a viziunilor ştiinţifice ale lui Constantin Stere," Revista Naţională de Drept, 12, București 2008, 2-6.

CENTRAL NATIONAL COUNCIL OF DOBROUDJA 1919

Central National Council of Dobroudja, "Memoir from the Central National Council of Dobroudja to the representatives of the states called together to restore the peace among the nations," Issue 2 of Dobroudja organisation in Bulgaria. Publications. Sofia 1919.

\section{CULEA 1928}

Apostol D. Culea, Cât trebuie să știe oricine despre Dobrogea, București 1928. 
DĂNESCU 1903

Grigore Dănescu, Dobrogea (La Dobroudja). Étude de Géographie physique etethnographique, Bucarest 1903.

DASKALOV, MISHKOVA 2013

Rumen Daskalov, Diana Mishkova, "Forms without substance: Debates on the transfers of Western models to the Balkans," in: Entangled Histories of the Balkans. Volume II. Transfers of political ideologies and institutions (ed. R. Daskalov and D. Mishkova), Leiden 2013, 1-99.

DASKALOV 1998

Roumen Daskalov, "Development in the Balkan Periphery Prior to World War II: Some Reflections," Südost-Forschungen, 57, Munich 1998, 207244.

DRAGOSTINOVA 2009

Theodora Dragostinova, "Navigating Nationality in the Emigration of Minorities between Bulgaria and Greece, 1919- 1941," East European Politics and Societies, 23, London 2009, 185-212.

HAMILAKIS 2007

Yannis Hamilakis, The Nation and Its Ruins: Antiquity, Archaeology, and National Imagination in Greece, Oxford 2007.

HITCHINS 1985

Keith Hitchins, The Idea of Nation: The Romanians of Transylvania, 16911849, Bucharest 1985.

\section{HITCHINS 1994}

Keith Hitchins, Rumania, 1866-1947, Oxford 1994.

IORDACHI 2000

Constantin lordachi, "'A románok Kaliforniája:' a roman határ kiterjesztése Észak-Dobrudzsában 1878-1913," in: Replika "A Roman történetírás kihivásai," (ed. C. Iordachi and B. Trencsényi), 10, Budapest 2000, 239-264.

IORDACHI 2002

Constantin lordachi, Citizenship, Nation- and State-building: The Integration of Northern Dobrogea into Romania, 1873-1913, Pittsburgh 2002.

IORGA 1910

Nicolae lorga, "Ce represintăm în Dobrogea?" ${ }_{L^{j}}$ Idei din conferința ținută în ziua de 11 ianuar 1910 de Nicolae lorga, Valenii de Munte 1910. 
140 |

\section{ISCHIRKOFF 1919}

Atanas Ischirkoff, Les Bulgares en Dobroudja. Apercu historique et ethnographique, Bern 1919.

ISHIRKOV 1918

Atanaslshirkov, La Dobroudja; géographie, histoire, ethnographie, importance économique et politique, Sofia 1918.

KARAKASIDOU 1997

Anastasia Karakasidou, Fields of wheat, hills of blood, Chicago 1997.

\section{KELLOG 1995}

Frederick Kellogg, The Road to Romanian Independence, West Lafayette, Ind. 1995.

\section{KUZMANOVA 1989}

Антонина Кузманова, От Ньой до Крайова, Въпросът за Южна Добруджа в международните отношения (1919-1940), София 1989.

\section{LIVEZEANU 1995}

Irina Livezeanu, Cultural Politics in Greater Romania: Regionalism, Nation Building \& Ethnic Struggle, 1918-1930, Ithaca 1995.

\section{MANIU 1919}

Iuliu Maniu “Dezbăterile Adunării deputaților, sesiunea ordinară 19191920, ședința din 22 decembrie 1919," in: Expozeul d-lui Iuliu Maniu la Camera în Patria, Cluj 1919.

\section{MANOILESCU 1991}

Mihail Manoilescu, Dictatul de la Viena, Memorii: iulie-august 1940, București 1991.

\section{MARINOV 2013}

Tchavdar Marinov, "Nations and national ideologies in the Balkans", in Entangled Histories of the Balkans. Volume I. National ideologies and language policies (ed. R. Daskalov, T. Marinov), Leiden 2013, 3-13.

MARKOV 1917

Milan Markov, The political fate of Dobroudja after the Berlin congress, Sofia 1917.

\section{MICHELSON 1987}

Paul M. Michelson, Conflict and Crisis: Romanian Political Development, 1861-1871, New York 1987. 


\section{MIHĂILESCU 1938}

Vintilă Mihăilescu, La Dobroudja, București 1938.

\section{MISHKOVA 1994}

Diana Mishkova, "Literacy and Nation-building in Bulgaria 1878-1912," East European Quarterly, 29, Boulder 1994, 63-93.

\section{MISHKOVA 2008}

Diana Mishkova, "Symbolic Geographies and Visions of Identity. A Balkan Perspective," European Journal of Social Theory, 11, London 2008, 237256.

\section{MYLONAS 2012}

Harris Mylonas, The Politics of Nation-building: Making Co-nationals, Refugees, and Minorities, New York 2012.

NYAGULOV ET AL. 2007

Благовест Нягулов, Володя Милачков, Антонина Кузманова и др. История на Добруджа Том 4, Велико Търново 2007.

\section{PENACOFF 1928}

Ivan Penacoff/Penakov, Le problem de la Dobroudja de Sud. Un aspect economique et social de ce problem, Sofia 1928/1940.

\section{RADEV 1913}

Симеон Радев, “Из рапорт на пълномощния министър в Букурещ С. Радев до министъра на външните работи Н. Генадиев относно мнението на австро-унгарската дипломация за мястото на Добруджа в българо-румънските отноения," 1913, Извори за историята на Добруджа, (ed. Ж. Борисов Попов, К. Пенчиков, П. Тодоров),_Том 1, София 1992, 237-238.

RADEV 1973

Симеон Радев, Строителите на съвременна България т. 1,2, София 1973.

ROUDOMETOF 2000

Victor Roudometof, "The Social Origins of Balkan Politics: Nationalism, Underdevelopment, and the Nation-State in Greece, Serbia, and Bulgaria, 1880-1920," Mediterranean Quarterly, 11, Durham 2000, 144163.

ROUDOMETOF 2002

Victor Roudometof, Collective memory, national identity and ethnic conflict. Greece, Bulgaria and the Macedonian question, Westport 2002. 
142 |

\section{SCHMIDT-RÖSLER 1994}

Andrea Schmidt-Rösler, Rumänien nach dem Ersten Weltkrieg, Frankfurt am Main 1994.

SCURTU 1983

Ioan Scurtu, Din viața politică a României (1926-1947) - Studiu critic privind istoria Partidului Național-Țărănesc, București 1983.

SEIȘANU 1928

Romulus Seișanu, Dobrogea, gurile Dunării și insula Șerpilor, București 1928.

SMITH 1995

Anthony Smith, "Civic and ethnic nationalism," in: Nations and

Nationalism (ed. P. Spencer and H.d Wollman), Edinburgh 1995, 177-183.

STERE 1922

Constantin Stere, " "Anteproiect de Constituție întocmit de secția de studii a Partidului Țărănesc," Viața Românească S.A., București 1922.

\section{STICHWEH 1997}

Rudolf Stichweh, "The Stranger - on the Sociology of the Indifference", Thesis Eleven, 51, London 1997, 1-16.

\section{STOICĂ 1919}

Vasile Stoică, The Dobrogea, New York 1919.

TODOROVA 2004

Maria Todorova, Balkan Identities: Nation and Memory, New York 2004.

UNGUREANU 2005

George Ungureanu, Chestiunea Cadrilaterului. Interese românești și revisionizm bulgar, 1938-1940, București 2005.

\section{VAKARELSKI 1964}

Христо Вакарелски, Добруджа: материали към веществената култура на българите през периода на капитализма, София 1964.

\section{VLĂDESCU 1926}

Christian Vlădescu, Bulgarii: memorile unui ofițer român fost prizonier in Bulgaria, București 1926. 